\title{
Experimental Evaluation of a Diesel Engine for Combustion, Performance and Exhaust Emissions with Fuel Blends Derived from a Mixture of Fish Waste Oil and Waste Cooking Oil Biodiesel
}

\author{
Muhammad Waqar Ghous Qureshi', Zahid Mehmood Khan', Mazhar Hussain', \\ Fiaz Ahmad $^{1}$, Muhammad Shoaib ${ }^{1}$, Muhammad Qasim ${ }^{3 *}$ \\ ${ }^{1}$ Department of Agricultural Engineering, Bahauddin Zakariya University, Multan, Pakistan \\ ${ }^{2}$ Institute of Chemical Sciences, Bahauddin Zakariya University, Multan, Pakistan \\ ${ }^{3}$ Hydrocarbon Development Institute of Pakistan (HDIP), Multan, Pakistan
}

Received: 16 March 2018

Accepted: 18 April 2018

\begin{abstract}
The production of biodiesel fuel for diesel engines from waste oil resources resolves a triple-faceted problem: environmental, economic and waste management. This study aimed to extract oil from fish waste, to convert the extracted oil into biodiesel fuel through base catalyzed transesterification and to reduce waste disposal-related environmental problems. Various fuel blends (CBFM10, CBFM20, CBFM30, CBFM40 and CBFM50) were prepared from a 1:1 mixture of waste canola oil biodiesel (WCOB) and transesterified fish waste oil (TFWO) with different proportions of mineral diesel. The mixture was named as the composite blends of fuel mixtures (CBFM). The fuel mixtures were subjected to physicochemical properties like kinematic viscosity, density, flash point and calorific values that were found with the international standard limits of biodiesel fuel and comparable to those of petroleum diesel with an added benefit to be lower in price being derived from waste resources. The formulated fuel blends were run in a $5.5 \mathrm{~kW}$ stationary diesel engine to investigate combustion, performance and emission characteristics. In comparison to petroleum diesel, slightly higher BSFC, marginally lower BTE and shorter ignition delay was observed with CBFM fuel blends. As compared to fossil fuel diesel carbon monoxide $(\mathrm{CO})$ and hydrocarbons $(\mathrm{HC})$ were found to decrease by $2.8-25.1 \%$ and $2.2-19.9 \%$, respectively. In comparison to all tested fuel blends, CBFM10 has shown lower nitrogen oxide emissions. The tested fuel blends were found to have great potential to be utilized as cheap and easily handled alternative fuels for compression ignition (CI) engines without any modification in any part of the engine.
\end{abstract}

Keywords: waste cooking oil, fish waste oil, diesel engine, combustion, performance, emissions

*e-mail: drqasimmazari@gmail.com 


\section{Introduction}

Global warming due to pollutant emissions from petroleum-based fuels, a shortage of crude oil supply due to a many-fold increase of its price, fast population growth, high costs, rapid depletion of fossil fuels, prompt industrialization and high costs have set researchers to explore cheap and environmentally friendly alternative fuels for diesel engines [1-3]. Worldwide, biodiesel is said to be a sustainable alternative fuel for mineral diesel. There are numerous advantages of blending biodiesel with diesel such as renewability, reduced emission of toxic pollutants, carbon neutrality and good lubricity as compared to petroleum diesel. Besides various advantages, some disadvantages have also been reported by some researchers such as higher production costs, less oxidation stability and more nitrogen oxide emissions in comparison to mineral diesel fuel [4]. Despite all the drawbacks, if the biodiesel is produced from waste resources, the merits mentioned earlier dominate over demerits to ensure the continued production of biodiesel [4].

An economic production of biodiesel is possible through potential feed stocks having substantial amounts of oil or lipids like waste cooking oil (WCO) and cotton seed oil as reported in various research studies [5-6]. The oil extracted from fish wastes has attracted a great deal of attention, being a good resource that does not trigger competition with food resources [4]. Because of the presence of high nutritional values, particularly eicosa-pentaenoic acid (EPA), omega-3 fatty acids and docosa-hexaenoic acid (DHA), the fish is excessively consumed world-wide. It has been observed that there is a wide range of applications for using fish oil, including medicinal uses [6]. From the caught fish a sufficient portion is being isolated as processing leftovers such as heads, fins, viscera, skin, frames and trimmings. More complete utilization is achieved by conversion of leftovers into fishmeal and fish oils. Indeed, the quantities of fish waste are estimated at several hundred thousand tons of waste per year [7], while experiments showed that depending on the species, tissue and season, recovery of fish oil from fish waste residue ranged 1.4-40.1\% [5]. Therefore, it would be useful to insist on the importance of treatment and recovery of fish waste to avoid any effect on the environment in general and on human health in particular. In fact, many recent studies were found to be interested in the valorization of fish waste. The one that has received the greatest attention is the synthesis of a biofuel that meets the security of supply criteria: response to local development needs ensuring the reduction of the production of $\mathrm{CO}_{2}-$ the main greenhouse gas emission. Biofuel is an alternative fuel for diesel engines. It can be used in its original form (B100) without blending with light hydrocarbon fractions, or might be blended at any concentration with mineral diesel to run as a fuel in diesel engines
[8-12]. The biodiesel yield ranges between 80 and $95 \%$ (weight percent) depending on the quality and the purity of the oil [13].

The edible vegetable oil becomes unsuitable for consumption after repeated frying for food preparation [14]. WCO also has many disposal problems like water and soil pollution, human health concerns, and disturbance to the aquatic ecosystem. The WCO may be effectively used for biodiesel production instead of its harmful environmental disposal options. The collected WCO might be used to prepare soap and additives for engine oils. Successful conversion of WCO into biodiesel has been documented by many researchers throughout the world [15]. Conversion of WCO into biodiesel contributes to lower greenhouse gas (GHG) emissions in comparison to conventional diesel [16]. Many scientists have recommended the suitability of vegetable oil and its derivatives to be utilized as fuel or as effective fuel additive [17].

The explored feed stocks for the production of fuel for diesel engines studied by various researchers for performance and exhaust emissions are palm oil [18], olive oil [19], castor oil [20], almond oil [21], cotton seed oil [22-23], pongamia oil [24], jathropha oil [25], rapeseed oil [26], mahua oil [27-28], rice bran [29], waste rapeseed and corn oil [30], safflower oil and milk scum oil [31]. On the basis of the results of these studies, it was revealed that the engines fueled with biodiesel derived from various feed stocks emit fewer pollutant emissions compared to that of diesel derived from crude oil. The engine performance results varied from the work of one researcher to another depending upon the nature of feed stocks, raw material and diesel engine life.

Without utilizing the energy contents available in the waste oils, a huge amount of waste energy sources are discharged as disposals. To be used as alternative fuels for diesel engines, many researchers have worked on fuel from waste resources, like waste cooking oil waste plastic and biofuels [32-34]. For the utilization of tire oil and waste lubricating oil as an engine fuel substitute, many experiments were carried out. In this connection, Mani et al. [35] studied the effective use of used plastic oil blends in a diesel engine. Waste oil reutilization in diesel engines by pyrolytic distillation methods was demonstrated [36, 37].

The aim of this study was to extract oil from fish wastes and to carry out experimental investigations on the fuel blends taken from a combination of oils derived from fish wastes and used cooking oil biodiesel-diesel mixtures in a diesel engine to assess the suitability of the fuel blends to be utilized as conventional diesel fuel substitute for diesel engines. Various physicochemical characteristics were measured and compared with diesel and biodiesel fuel standard specifications. Different Combustion, performance and emission parameters of the engine were studied. 
Table 1. CBFM and its blend compositions.

\begin{tabular}{|c|c|c|c|c|c|}
\hline \multirow{2}{*}{$\begin{array}{c}\text { Sr. } \\
\text { No. }\end{array}$} & \multirow{2}{*}{ Fuel Blend Type } & \multicolumn{2}{|c|}{ CBFM Description } & \multicolumn{2}{c|}{ CBFW-Diesel Blend Descriptions } \\
\cline { 3 - 6 } & & TFWO Volume $(\mathrm{mL})$ & WCOB Volume $(\mathrm{mL})$ & CBFW Volume (mL) & Diesel Volume (mL) \\
\hline 1 & Diesel (CBFM0) & - & - & 0 & 1000 \\
\hline 2 & CBFM10 & 500 & 500 & 100 & 900 \\
\hline 3 & CBFM20 & 500 & 500 & 200 & 800 \\
\hline 4 & CBFM30 & 500 & 500 & 300 & 700 \\
\hline 5 & CBFM40 & 500 & 500 & 400 & 600 \\
\hline 6 & CBFM50 & 500 & 500 & 500 & 500 \\
\hline 7 & CBFM100 & 500 & 500 & 1000 & 0 \\
\hline
\end{tabular}

\section{Experimental Formulation}

\section{Samples Description}

The fish waste oil was extracted from fish wastes collected from a fish farm located near Multan, Pakistan using an indigenously developed machine. Two liters of waste cooking oil (known to be canola oil) were taken from M/S Al-Rehman Food Restaurant located in the city of Multan, Pakistan. Fish waste oil and waste canola oil were converted into biodiesel through transesterification reaction as explained in section 2.3. The transesterified fish waste oil (TFWO) and waste canola oil biodiesel (WCOB) were mixed in a ratio of 50:50 to form a fuel blend named as composite blends of fuel mixtures (CBFM). As detailed in Table 1, the
CBFM was further mixed with petroleum diesel in different proportions.

\section{Extraction of Oil from Fish Wastes}

A crusher, centrifuge system and cooker are main parts of the developed extraction system. The centrifuge system and crusher contain 2 and 1 hp electric motors, respectively. The revolution capacity of the motor was $1450 \mathrm{rpm}$. A fully water-filled double jacket system was coupled with an agitator installed in the cooker. A $1 \mathrm{hp}$ electric motor was provided to operate an agitator at $40 \mathrm{rmp}$. The centrifuge unit had a double screening mechanism. An appropriate amount of fish waste, including intestines, livers, tail, etc., was fed into the crushing unit. The waste material

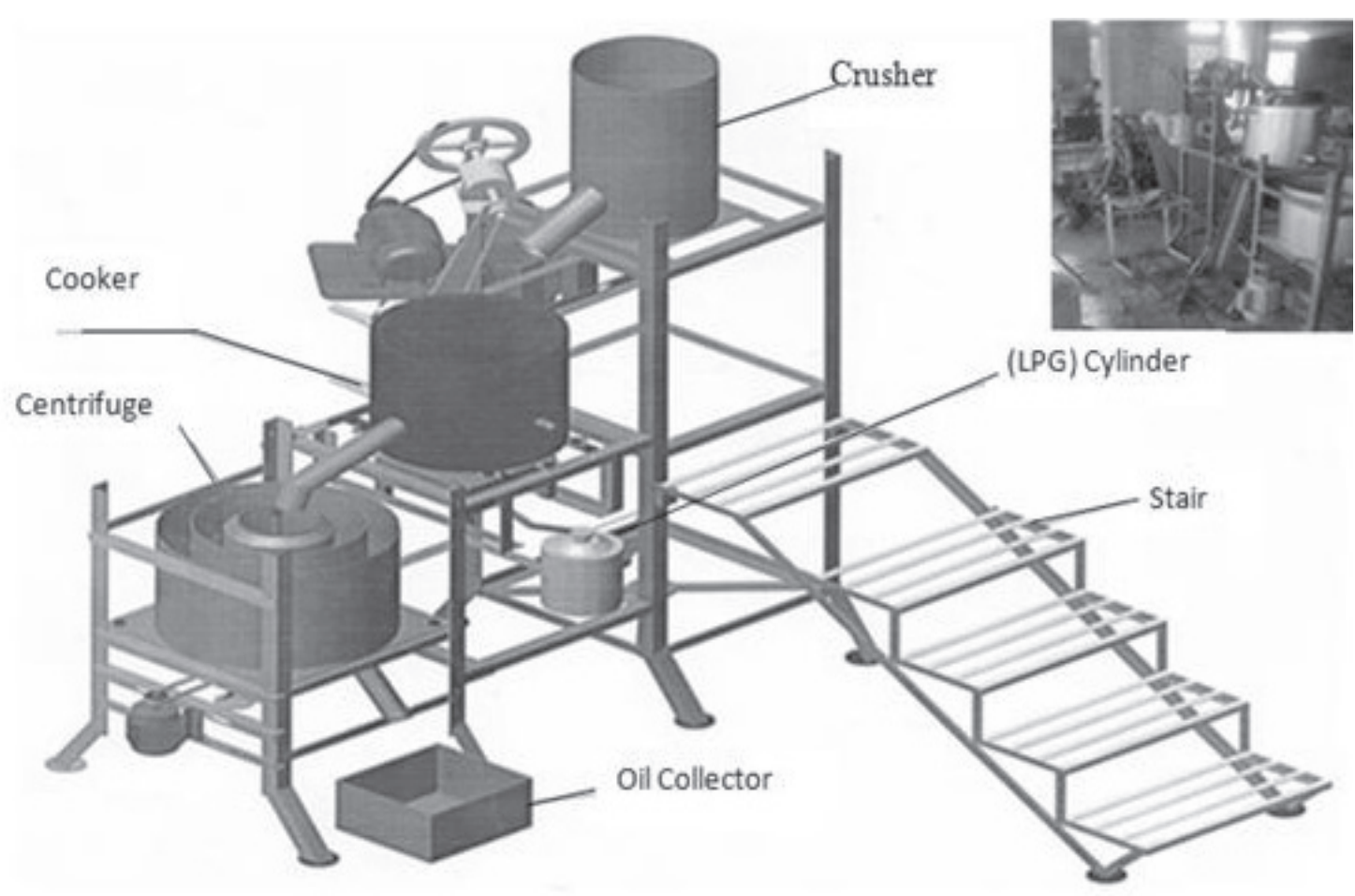

Fig. 1. Schematic diagram of fish waste oil extraction pilot plant. 
was shifted to the cooking unit after crushing. A heat source of the cooking unit increased the temperature inside the cooker so that the waste was cooked properly. Then the cooked material was transferred into a centrifuge for separation of oil from the solid components. After completing one batch, the crusher cylinder was loaded for the next batch and the above procedure was repeated. The rigorous testing for characterization was carried out of the fish oil extracted from the current indigenously developed pilot plant. The developed extraction unit is shown in Fig. 1.

\section{Transesterification Process}

The first step of the transesterification process was the production of sodium methoxide. To have a solution of sodium methoxide prepared, $3.70 \mathrm{~g}$ of sodium hydroxide $(\mathrm{NaOH})$ was dissolved in $200 \mathrm{~mL}$ methanol (200 $\mathrm{ml}$ by volume) available in a flask of $500 \mathrm{ml}$. In order to remove moisture contents from the fish waste oil (FWO), the oil was heated at $110^{\circ} \mathrm{C}$ for about 2 hrs. so that the FWO became dehydrated. The dehydrated FWO was cooled to about $50^{\circ} \mathrm{C}$. One $\mathrm{kg}$ of this preheated FWO was mixed with the already prepared sodium methoxide solution. The sodium methoxide solution mixture having FWO was constantly stirred with a magnetic stirrer on hot plate at $55^{\circ} \mathrm{C}$ for approximately $1 \mathrm{hr}$ to complete the transesterification process, after which the heating was continued for 30 minutes more even after removing the flask cover so that extra methyl alcohol could be removed. The mixture was allowed to cool after removal from the hot plate. After this step, the cooled mixture was kept in the separating funnel and left untouched for about $48 \mathrm{hrs}$.
Inside the funnel, two different layers of the liquid were observed. The upper layer was transesterified fish waste oil (TFWO) being called fish waste oil biodiesel (methyl esters), and the lower heavier layer was glycerin. The biodiesel layer (top layer) was separated and subjected to further purification process by washing with ultrapure de-ionized water and dried with sodium sulphate $\left(\mathrm{Na}_{2} \mathrm{SO}_{4}\right)$. After completing this process, a filtration process was carried out to get biodiesel derived from FWO in pure form. The same procedure was applied for conversion of used cooking oil into methyl esters (biodiesel). After completion of biodiesel preparation from FWO and cooking waste oil, various blends were prepared by mixing with different proportions of mineral diesel as given in Table 1 in section 2.1. Biodiesel produced using this procedure has already been reported in previous latest research [38, 39].

\section{Engine Setup}

The experiments were conducted in a stationary $5.5 \mathrm{~kW}$, water cooled, single cylinder, four stroke, naturally aspirated (NA) compression ignition engine. The schematic diagram of experimental arrangement is given in Fig. 2.

The engine had a stroke and bore of $110 \mathrm{~mm}$ and $87.5 \mathrm{~mm}$, respectively. The engine was run at 17.5:1 compression ratio. The injection timing was set as 23 bTDC (before top dead center). In order to measure the fuel flow rates, weighing scale (electronic) was used. The outer temperature of the exhaust gas was measured directly from the thermocouples. AVL DiGas 444 (AVL, Graz, Austria) exhaust gas analyzer was used to measure air pollutants like $\mathrm{CO}, \mathrm{HC}$ and $\mathrm{NO}_{\mathrm{x}}$ emissions.

For measuring smoke density we used an AVL 437 smoke meter (Graz, Austria). Calibration of each

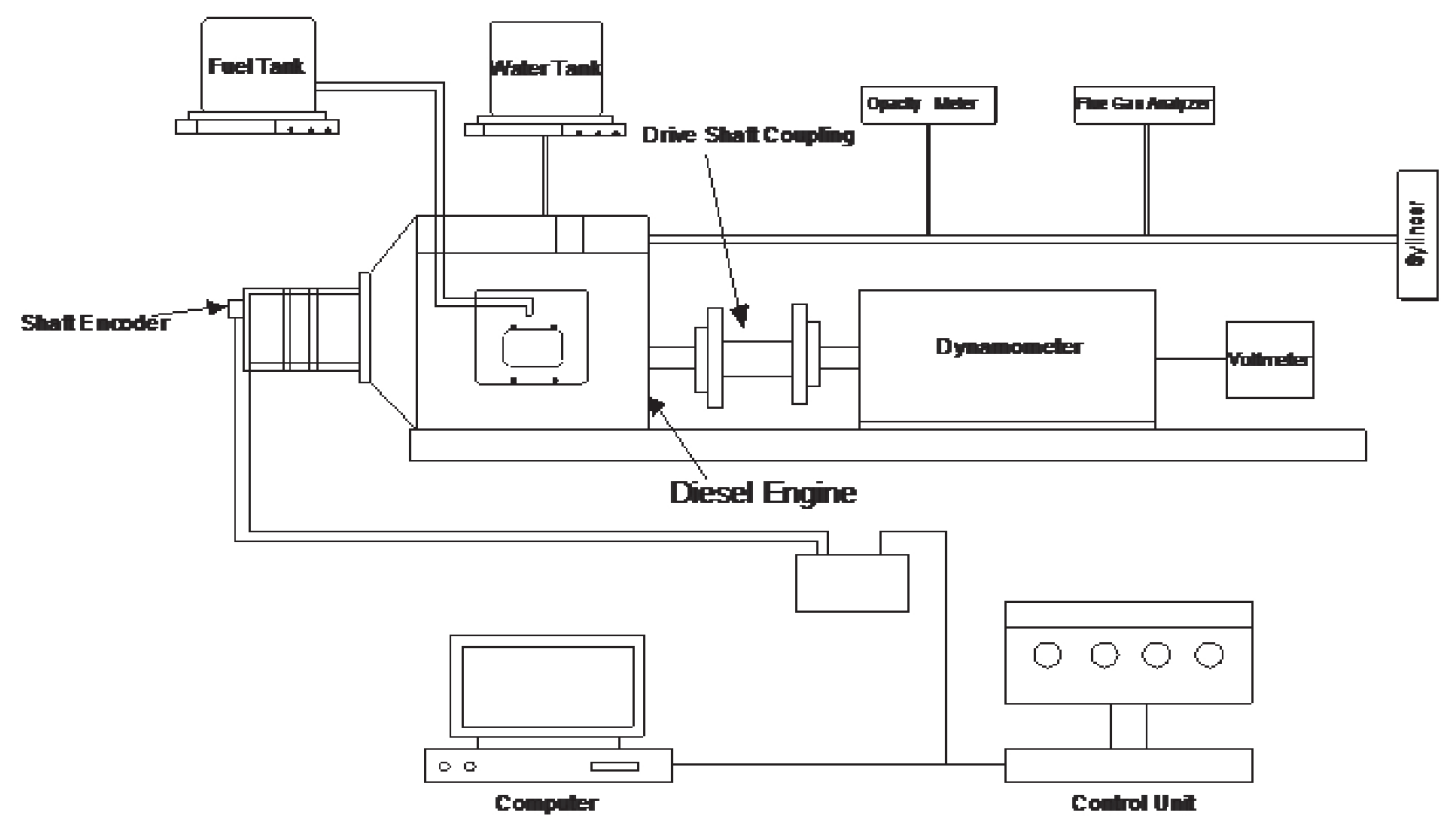

Fig. 2. Diagram of experimental set up. 
Table 2. Engine specifications.

\begin{tabular}{|c|c|c|}
\hline & Description & Specifications \\
\hline \multirow{10}{*}{ Engine } & Type & Water-cooled, four stroke \\
\hline & Engine model & Kirolaskar TAF-1 \\
\hline & Power $(\mathrm{kW})$ & 5.5 \\
\hline & Cylinders & 1 \\
\hline & Speed (rpm) & 1600 \\
\hline & Ratio of compression & $17.5: 1$ \\
\hline & Bore & $87.5 \mathrm{~mm}$ \\
\hline & Stroke & $110 \mathrm{~mm}$ \\
\hline & Injection timing & $23^{\circ}$ before TDC \\
\hline & Combustion & Direct injection (DI) \\
\hline \multirow{13}{*}{$\begin{array}{l}\text { Exhaust } \\
\text { gas } \\
\text { analyzer }\end{array}$} & Equipment & AVL Di Gas 444 \\
\hline & \multicolumn{2}{|c|}{$\mathrm{HC}(\mathrm{ppm})$} \\
\hline & Detection limit & 0 to 30,000 \\
\hline & Resolution & 1 \\
\hline & Accuracy & $\pm 4 \%$ \\
\hline & \multicolumn{2}{|c|}{$\mathrm{CO}(\%)$} \\
\hline & Detection limit & 0 to 15 \\
\hline & Resolution & 0.001 \\
\hline & Accuracy & \pm 0.06 \\
\hline & \multicolumn{2}{|c|}{ NOx $(\mathrm{ppm})$} \\
\hline & Range & 0 to 5,000 \\
\hline & Resolution & 1 \\
\hline & Accuracy & $\pm 2 \%$ \\
\hline \multirow{5}{*}{$\begin{array}{l}\text { Smoke } \\
\text { meter }\end{array}$} & Equipment & AVL 437 \\
\hline & Detection limit & $0-100 \%$ \\
\hline & $\begin{array}{l}\text { Alarming signal } \\
\text { tempertaure }\end{array}$ & $70^{\circ} \mathrm{C}$ \\
\hline & Accuracy & $\pm 1 \%$ \\
\hline & Light Source & Halgen Lamp, 12V \\
\hline
\end{tabular}

analyzer was performed before each test. In order to obtain the reference data the engine was run initially with diesel for no load, $20 \%, 40 \%, 60 \%, 80 \%$ and full load. Similarly, the engine was again run with diesel after conducting all tests with blends so as to clean the traces of different blends. The technical specifications of the engine are listed in Table 2.

For measuring the combustion pressure, an electric sensor (model number 6258c, made in Switzerland) was used. On the basis of pressure crank angle, the ignition delay was calculated by using Equation (1).

$$
\text { Ignition delay }=3.45 \times 10^{(2100 / \mathrm{Tm})} \mathrm{Pm}-1.02
$$

...where Pm stands for mean pressure and Tm stands for mean temperature occurring at time of ignition delay. The HRR of fish waste oil-derived blends was calculated with the help of the below-mentioned formula.

$$
\begin{gathered}
\Delta \mathrm{Q} / \Delta \theta=(1 / \mathrm{K}-1 \times \mathrm{V} \times \Delta \mathrm{P} / \Delta \theta) \\
+(\mathrm{K} / \mathrm{K}-1 \times \mathrm{P} \times \Delta \mathrm{V} / \Delta \theta)
\end{gathered}
$$

...where $\Delta \mathrm{Q} / \Delta \theta$ is equal to the HRR, $\Delta \mathrm{V} / \Delta \theta$ shows cylinder volume variations, $\mathrm{K}$ indicates specific heat ratio (1.35) and $\Delta \mathrm{P} / \Delta \theta$ corresponds to the change in pressure. Experiments were carried out at no load, 20\% load, 40\% load, 60\% load, $80 \%$ load and $100 \%$ load. Engine speed was kept at $1500 \mathrm{rpm}$.

\section{Results and Discussion}

Using standard procedures, statistical analysis was carried out for all the measurements, and all the results presented are the mean of three consecutive measurements.

\section{Physicochemical Characteristics}

The proposed blends CBFM10, CBFM20, CBFM30, CBFM40 and CBFM50 were studied for various characteristics such as density, viscosity, flash point, water contents, calorific value and cetane number as reflected in Table 3. Density was found to vary from $836-870 \mathrm{Kg} / \mathrm{m}^{3}$, viscosity varied from $3.14-4.28 \mathrm{cSt}$, flash point was found in the range of $65-120^{\circ} \mathrm{C}$, water contents ranged 48-182 ppm, calorific value was observed as 39.76-42.25 $\mathrm{MJ} / \mathrm{Kg}$ and cetane number was found in the range 44.0-54.5. This type of study was carried out by Qasim et al. (2017) as reported in literature [39]. The results of all these parameters have been compared with international fuel standards of diesel (ASTM 975) as well as European (EN14214) and American standards (ASTM 6751) of biodiesel. The analysis results of all the samples were found within the specified range of international fuel standards.

\section{Combustion Analysis}

Ignition delay is the measurement of difference of time in the degree of the crank angle between the start of fuel injection and fuel ignition in a diesel engine [34]. The rate of maximum pressure, pressure rise, and HRR can be determined using ignition delay values [34]. Fig. 3 shows the ignition delay of the engine fueled with CBFM blends and diesel at no load to $100 \%$ engine load. As the engine load was increased, the fall of ignition delay was observed due to the fact that the increase of engine load is parallel to that of brake power, thereby increasing the heat prevailing inside the combustion chamber. This phenomenon causes the fuel 
Table 3. Physico-chemical characteristics of CBFM fuel blends compared with diesel and biodiesel standards.

\begin{tabular}{|c|c|c|c|c|c|c|c|}
\hline \multirow[t]{2}{*}{ No. } & \multirow[t]{2}{*}{ Nomenclature } & Viscosity & Density & F.P & $\begin{array}{c}\text { Water Con- } \\
\text { tents }\end{array}$ & C.V & \multirow{2}{*}{$\begin{array}{l}\text { Cetane } \\
\text { Number }\end{array}$} \\
\hline & & $\mathrm{cSt}$ & $\mathrm{Kg} / \mathrm{m}^{3}$ & ${ }^{\circ} \mathrm{C}$ & ppm & $\mathrm{MJ} / \mathrm{kg}$ & \\
\hline 1 & Method (ASTM) & D-445 & D-1298 & D-93 & D-95 & D-240-17 & D-976 \\
\hline 2 & CBFM 10 & 3.24 & 840 & 72 & 48 & 42.25 & 47.0 \\
\hline 3 & CBFM20 & 3.33 & 851 & 78 & 65 & 41.33 & 46.0 \\
\hline 4 & CBFM30 & 3.66 & 858 & 88 & 82 & 40.78 & 45.0 \\
\hline 5 & CBFM40 & 3.98 & 865 & 103 & 156 & 40.60 & 45.0 \\
\hline 6 & CBFM50 & 4.28 & 870 & 120 & 182 & 40.35 & 44.0 \\
\hline 7 & CBFM0(Diesel) & 3.14 & 836 & 65 & Nil & 39.76 & 54.5 \\
\hline \multirow[t]{4}{*}{8.} & \multicolumn{7}{|c|}{ Specifications } \\
\hline & i) ASTM 6751 & $3.5-5.0$ & - & $>120$ & $<500$ & - & - \\
\hline & ii) En 14214 & $2.5-6.0$ & $860-900$ & $>120$ & $<500$ & - & - \\
\hline & iii) ASTM D975 & $1.3-4.1$ & - & $60-80$ & $<500$ & - & $40-55$ \\
\hline
\end{tabular}

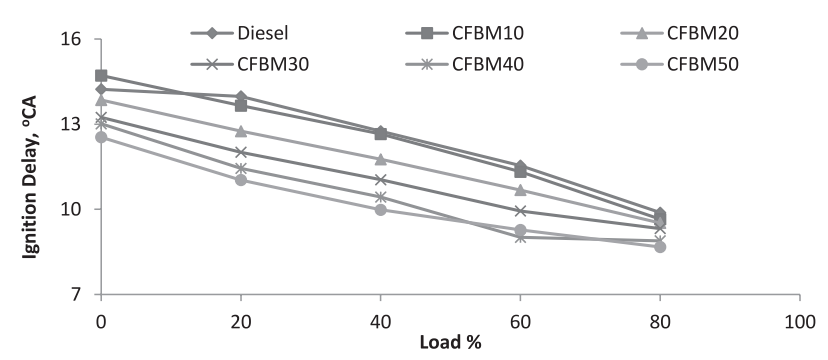

Fig. 3. Ignition delay with various engine load percentages.

air mixture to ignite sooner. It was found that the greater the CBFM portion in the samples, the lower the ignition delay. The observed ignition delay for diesel was about $9.88^{\circ} \mathrm{CA}$ and for CBFM10, CBFM20, CBFM30, CBFM40 and CBFM50 it was 9.65, 9.52, 9.32, 8.89 and $8.67^{\circ} \mathrm{CA}$, respectively, at full engine load percent. The ignition delay of CBFM10 was seen to be nearer to that of diesel among all the fuel blends analyzed. The shorter ignition delay of the tested fuel blends may be attributed to the availability of higher contents of oxygen present in biodiesel fuel [41]. It was experimentally observed that the shorter ignition was responsible for better consumption of fuel [41].

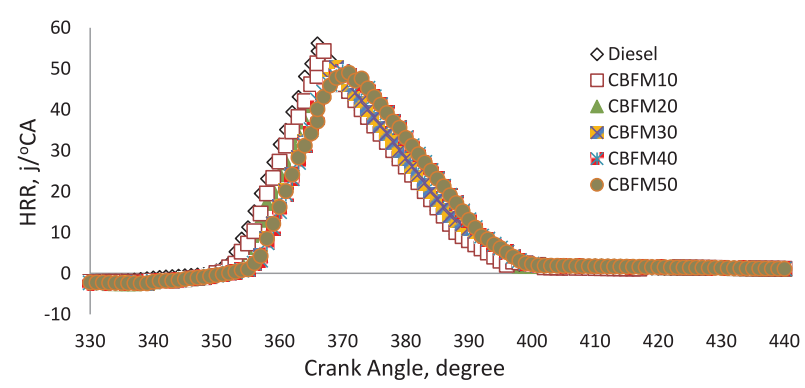

Fig. 4. Variations of HRR with cranke angle, degree.
Fig. 4 shows the HRR values of petroleum diesel and CBFM fuel blends at various engine load conditions. As per studies of Heywood (1988) [40], in the beginning of combustion, the HRR varies with ignition delay, mixture formation and the rate at which the combustion is occurring. At full engine load, the maximum HRR for diesel was found at $364.2^{\circ} \mathrm{C}$ and for the CBFM10, CBFM20, CBFM30, CBFM40 and CBFM50 the HRR was observed at 366.4, 367.4, 368.1, 369.0 and $370.3^{\circ} \mathrm{C}$, respectively. The crank angle was observed to be advanced and HRR was found to decrease as the proportion of CBFM in the blend was increased.

The cylinder pressure changes at various engine loads for analyzed fuel samples (Fig. 5). Generally, at the initial stages of premixed combustion phase, the maximum cylinder pressure of a diesel engine was found to be dependent on the rate of combustion and the fuel proportion accrued in the delay period as reported by Raheman et al. (2013) [36]. For diesel, CBFM10, CBFM20, CBFM30, CBFM40 and CBFM50, the maximum cylinder pressure was found as 72.33 , $75.28,77.28,79.56,80.42$ and 82.56 bars, respectively, at full engine load. Higher values of the $100 \%$ cylinder pressure were observed with CBFM fuel blends in comparison to that of mineral diesel at full load

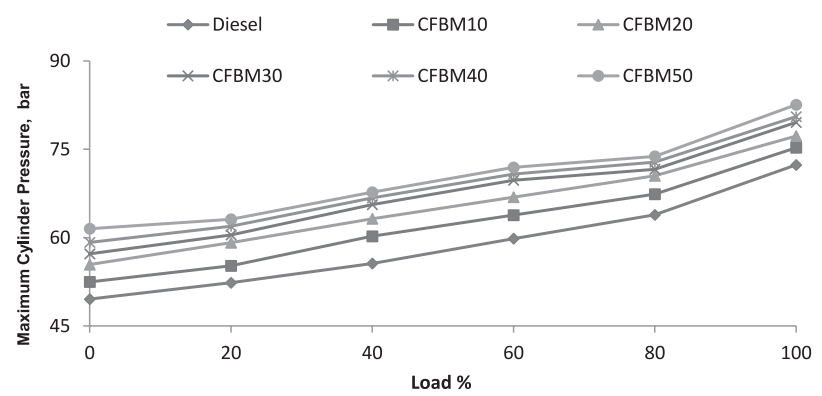

Fig. 5. Cylinder pressure with various engine load percentages. 


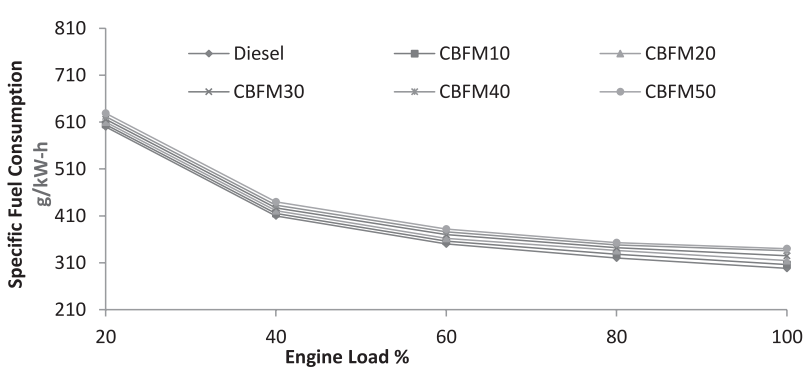

Fig. 6. BSFC with various engine load percentages.

conditions. This cylinder pressure increase for fuel blends might be due to the higher HRR in the phase of premixed combustion [42].

\section{Engine Performance}

The BSFC of the engine with diesel and CBFM blends at various engine loads has been given in Fig. 6. Along with the increase in engine load, fuel consumption was found to decrease with all the fuel blends analyzed. However, in comparison to diesel fuel, the rise in BSFC was found with CBFM blends. At full engine load, the sample CBFM10 showed the lowest value of BSFC (306.2 $\mathrm{g} / \mathrm{kWh})$. In contrast, CBFM50 has shown the highest BSFC as $340.2 \mathrm{~g} / \mathrm{kWh}$ - possibly due to its greater viscosity. The BSFC values for diesel, CBFM10, CBFM20, CBFM30, CBFM40 and CBFM50 were found as 298.0306.2, 314.6, 324.8, 335.7 and $340.2 \mathrm{~g} / \mathrm{kWh}$ respectively at maximum engine load. It has been experimentally observed that along with the increase of engine load, the fuel consumption was found to decrease $[40,42]$ due to the lower amount of heat loss the engine might have faced [40].

The BTE of the engine with diesel and CBFM fuel blends at various engine load conditions is given in Fig. 7. At full engine load, the brake thermal efficiency of diesel was found as $25.30 \%$ and the engine BTE values for CBFM10, CBFM20, CBFM30, CBFM40 and CBFM50 were found as $24.9 \%, 24.2 \%, 23.6 \%, 22.9 \%$ and $22.4 \%$, respectively, with a marginal decrease of $1.58 \%, 4.34 \%, 6.71 \%, 9.48 \%$ and $11.46 \%$, respectively. The fuel blends CBFM10 (1.58\%) and CBFM20 (4.34\%) have shown less of a decrease of BTE among other fuel blends. Along with increase in engine load and CBFM

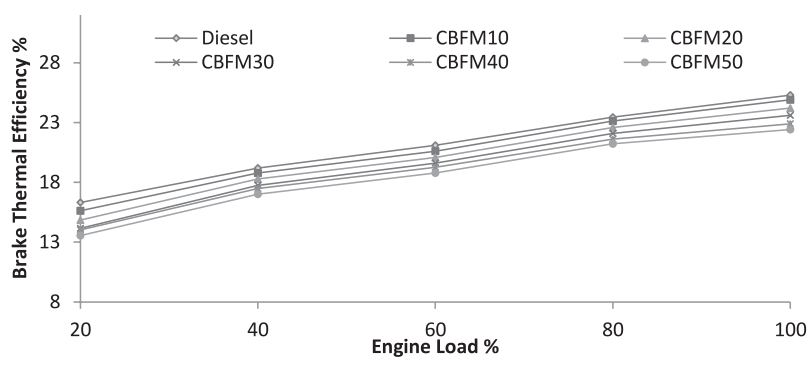

Fig. 7. BTE with various engine load percentages.

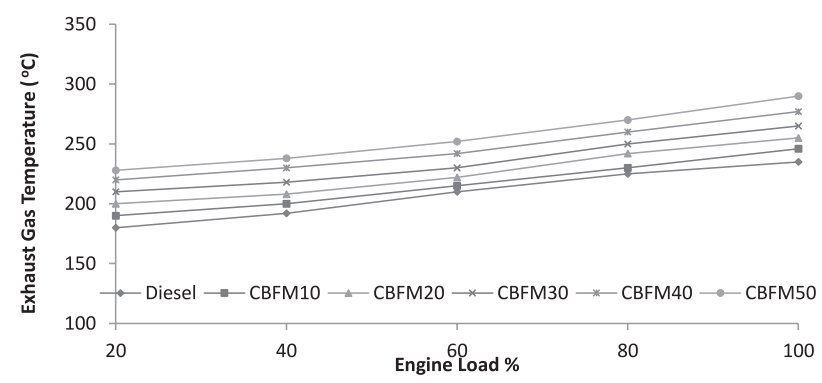

Fig. 8. EGT with various engine load percentages.

proportions in fuel samples, BTE was observed to rise. This was because of lower calorific values of CBFM as compared to that of petroleum diesel [32] and the engine's heat losses at increased loads [35]. CBFM10 has shown greater thermal efficiency $(24.9 \%)$ among all fuel blends tested, and the value was found to be nearer to that of diesel $(25.30 \%)$.

Fig. 8 shows the EGT of the engine with diesel and CBFM fuel blends at different engine load conditions. The exhaust gas temperature of petroleum diesel was found as $235.0^{\circ} \mathrm{C}$ and for CBFM10, CBFM20, CBFM30, CBFM40 and CBFM50 were found as $246.7^{\circ} \mathrm{C}, 255.1^{\circ} \mathrm{C}$, $265.4^{\circ} \mathrm{C}, 277.6^{\circ} \mathrm{C}$ and $290.6^{\circ} \mathrm{C}$, respectively, with an increase of $4.97 \%, 8.55 \%, 12.93 \%, 18.12 \%$ and $23.65 \%$, respectively. For the purpose of creating extra power to overcome the additional load, the engine needed higher fuel amounts, so the EGT of the engine was increased with fuel blends [40, 42]. This type of technical study has been carried out by many researchers [43-48].

\section{Engine Emissions}

Fig. 9 shows the $\mathrm{HC}$ emissions of the engine with diesel and CBFM fuel blends at various load conditions. At maximum engine load, the $\mathrm{HC}$ emissions with diesel, CBFM10, CBFM20, CBFM30, CBFM40 and CBFM50 were found to be $0.45,0.44,0.42,0.0 .39,0.37$ and $0.36 \mathrm{~g} / \mathrm{kW} \mathrm{h}$, respectively. The decrease of $2.2 \%, 6.7 \%$, $13.3 \%, 17.8 \%$ and $19.9 \%$ HC emissions was observed for CBFM10, CBFM20, CBFM30, CBFM40 and CBFM50, respectively, in comparison to petroleum diesel. This decrease is a good sign because, as a result of excellent combustion with better atomization, the decreased values of $\mathrm{HC}$ emissions could be observed [48, 49].

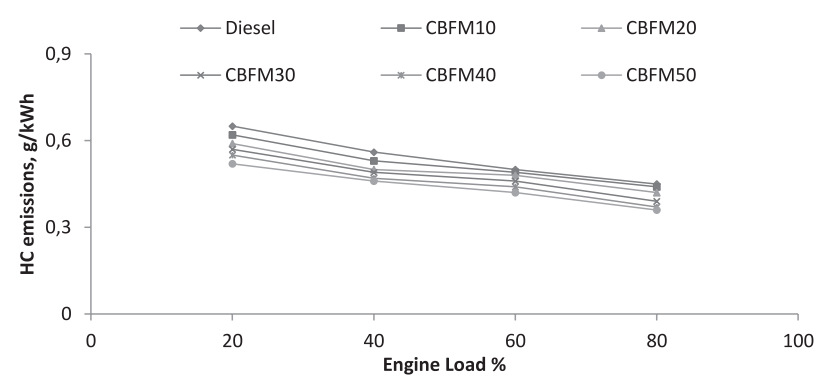

Fig. 9. HC emissions with various engine load percentages. 


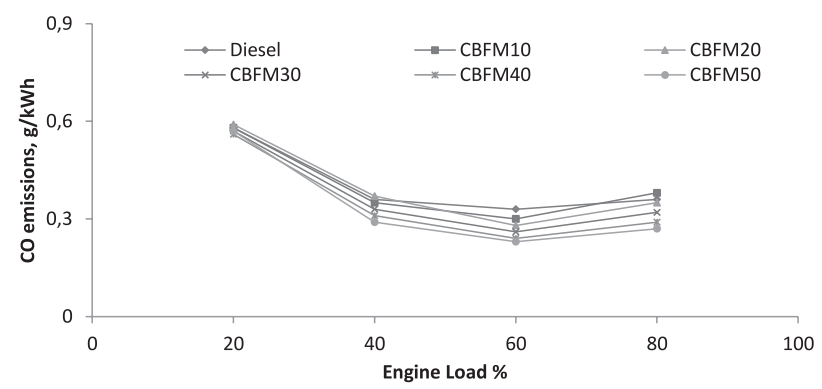

Fig. 10. CO emissions with various engine load percentages.

The $\mathrm{CO}$ emissions of the engine with diesel and CBFM fuel blends at various loads of the engine have been shown in Fig. 10. The $\mathrm{CO}$ emission of the engine with diesel, CBFM10, CBFM20, CBFM30, CBFM40 and CBFM50 was found to be $0.36,0.36,0.35,0.32$, 0.29 and $0.26 \mathrm{~g} / \mathrm{kW} \mathrm{h}$, respectively. The blend CBFM10 has shown similar $\mathrm{CO}$ emission values to that of diesel. Along with an increase in CBFM blend concentrations and with increasing engine load, the $\mathrm{CO}$ emission was found to decrease. At full engine load, as compared to CBFM10 and diesel CO emissions with CBFM20, CBFM30, CBFM40 and CBFM50 it was found to decrease by $2.8 \%, 11.1 \%, 19.4 \%$ and $25.1 \%$, respectively. Inside the engine, more complete combustion of the fuel might be evidenced with decreased $\mathrm{CO}$ emissions as reported by Dolanimi et al. [49].

The $\mathrm{NO}_{\mathrm{x}}$ emissions of the engine with mineral diesel as well as CBFM fuel blends at various engine load conditions are given in Fig. 11. The $\mathrm{NO}_{\mathrm{x}}$ emissions of the engine with diesel were found as $6.6 \mathrm{~g} / \mathrm{kWh}$ and with CBFM10, CBFM20, CBFM30, CBFM40 and CBFM50, the $\mathrm{NO}_{\mathrm{x}}$ emissions were found as 6.7, 6.9, 7.3, 7.4 and $7.9 \mathrm{~g} / \mathrm{kWh}$, respectively, with a slight increase of $4.4 \%, 7.8 \%, 14.0 \%, 15.6 \%$ and $23.4 \%$, respectively. Among all the fuel blends tested, CBFM10 has shown lower $\mathrm{NO}_{\mathrm{x}}$ emissions. Along with an increase in CBFM proportion in the fuel blends, The $\mathrm{NO}_{\mathrm{x}}$ emission was found to increase. Higher EGT and extended oxygen concentrations in the biodiesel proportion of the CBFM fuels may be the reasons for increased values of $\mathrm{NO}_{\mathrm{x}}$ emissions [41].

The smoke emissions of the engine with diesel and CBFM10, CBFM20, CBFM30, CBFM40 and CBFM50 at various engine load conditions are given in Fig. 12.

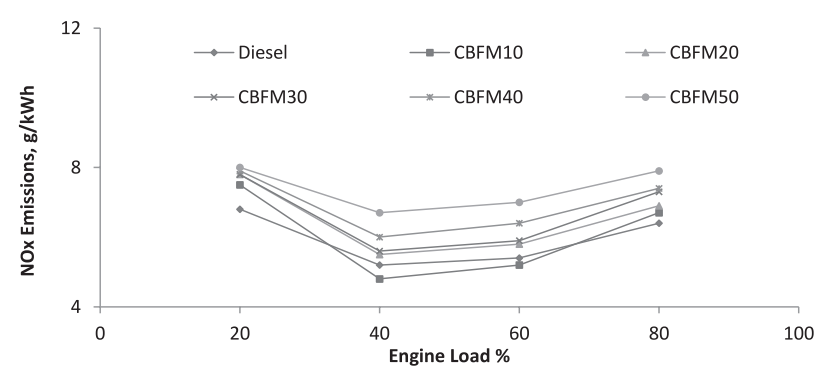

Fig. 11. $\mathrm{NO}_{\mathrm{x}}$ emissions with various engine load percentages.

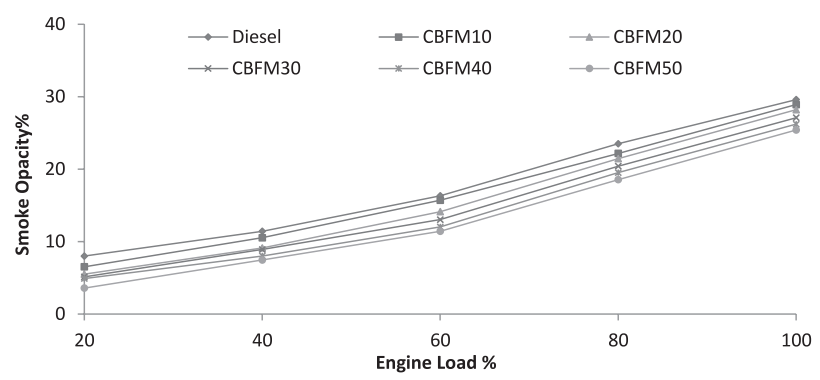

Fig. 12. Smoke opacity with various engine load percentages.

The smoke emission of CBFM blends was lower than that of diesel. As the concentration of composite blends was increased, the smoke opacity of CBFM blends decreased. Highest smoke emission was shown with CBFM10, and the lowest value was observed with CBFM50 among all the investigated fuel blends. The smoke emissions of the engine with CBFM10, CBFM20, CBFM30, CBFM40, CBFM50 and petroleum diesel was observed to be $29.5 \%, 28.9 \%, 28.2 \%, 27.1 \%, 26.2 \%$ and $25.4 \%$, respectively, at maximum engine load. Inside the engine, the incomplete combustion of fuel may cause smoke emissions [50]. Lower smoke emissions always indicate better combustion of the fuel inside the engine $[38,50]$.

\section{Conclusions}

In the present study, the oil was extracted from fish wastes and successfully converted into biodiesel fuel through base catalyzed transesterification reaction. The composite blends of fuel mixtures (CBFM10, CBFM20, CBFM30, CBFM40 and CBFM50) obtained from a mixture of transesterified fish waste oil (TFWO) and waste cooking oil (canola oil) biodiesel (WCOB) with various proportions of petroleum diesel were investigated in a diesel engine for combustion, performance and emission parameters. The physicochemical properties were measured by using ASTM standards. On the basis of analysis results, the important conclusions are as follows:

- The results of all the physico-chemical parameters of CBFM blends were found within the specified limits of international fuel standards of diesel (ASTM 975), as well as European (EN14214) and American standards (ASTM 6751) of biodiesel.

- Marginally, higher values of BSFC were observed with CBFM fuel blends as compared to those of diesel fuel. Lowest BSFC was observed for CBFM10 $(306.2 \mathrm{~g} / \mathrm{kW} \mathrm{h})$ and highest value was observed for CBFM50 (340.6g/kW h).

- All CBFM blends exhibited slightly lower BTE value as compared to that of diesel. CBFM10 has shown greater thermal efficiency $(24.9 \%)$, and the value is closer to that of diesel $(25.30 \%)$ among all investigated CBFM blends. 
- Compared to diesel, in all analyzed CBFM blends, shorter ignition delay was observed. This is good evidence for better combustion of proposed fuel blends.

- Compared to diesel fuel, 2.8-25.1\% and 2.2-19.9\% decreased values of $\mathrm{CO}$ and $\mathrm{HC}$ emissions were observed for overall CBFM fuel blends.

- As compared to fossil fuel diesel, there was a significant decrease in smoke emissions of CBFM fuel blends.

- Emissions of nitrogen oxide were found to increase with increases in engine load. Among the fuel samples investigated, CBFM10 has shown lower $\mathrm{NO}_{\mathrm{x}}$ emissions.

- The operation of the engine was successful with CBFM blends, no engine failure was observed with any fuel blend analyzed. The best performance was noted with CBFM10 among the analyzed fuels.

This work is the first demonstration to have energy from available waste resources in a developing country like Pakistan. These waste resources have a great potential to be used in diesel engines as a fuel. Some more extensive research is required to bring the proposed process at a commercial level.

\section{Abbreviations}

FWO - Fish waste oil

WCOB - Waste canola oil biodiesel

CBFW - Composite blends of fish waste oils (50\% fish waste oil biodiesel plus 50\% waste canola oil biodiesel)

CBFW10 - 10\%CBFW and 90diesel (fossil fuel)

CBFW20 - 20\% CBFW and 80\% diesel (fossil fuel)

CBFW30 - 30\% CBFW and 70\% diesel (fossil fuel)

CBFW40 - 40\% CBFW and 60\% diesel (fossil fuel)

CBFW50 - 50\% CBFW and 50\% diesel (fossil fuel)

obTDC - Before top dead center

TFWO - Trans-esterified fish waste oil

WCOB - Waste canola oil biodiesel

BTE - Brake thermal efficiency

SI - Smoke intensity

EGT - Exhaust gas temperature

$\mathrm{HC}$ - Hydrocarbons

$\mathrm{CO}$ - Carbon monoxide

BSFC - Brake specific fuel consumption

$\mathrm{NOx}$ - Oxides of nitrogen

NA - Naturally aspirated

\section{Acknowledgements}

This work is part of the Ph.D. research of Muhammad Waqar Ghous Qureshi. The authors are grateful to the Department of Agricultural Engineering, Bahauddin Zakariya University, Multan, Pakistan, Institute of Chemical Sciences, BahauddinZakariya University, Multan, Pakistan and Hydrocarbon Development
Institute of Pakistan, Multan and M/S Servo Motor Oil (Pvt.) Limited, Multan, Pakistan for cooperation and technical support.

\section{Conflict of Interest}

The authors have not declared any conflict of interest.

\section{References}

1. YOON S.H., CHA P.J., LEE C.S. An investigation of the effects of spray angle and injection strategy on dimethyl ether (DME) combustion and exhaust emission characteristics in a common-rail diesel engine. Fuel Processing Technology. 91 (11), 13642, 2010.

2. QASIM M., ANSARI T.M., MAZHAR H. Preparation, Characterization and Engine Performance of Biodiesel Fuel Derived from Waste Cooking Oil and its Blends. Inter J Sciences. 6 (4), 113, 2017. http://www.ijsciences.com/pub/ issue/2017-04/

3. LI L., WANG J., WANG Z., XIAO J. Combustion and emission characteristics of diesel engine fueled with diesel/biodiesel/pentanol fuel blends. Fuel. 15 (6), 211, 2015.

4. SHARMA Y.C., SINGH B., UPADHYAY S.N. Development of biodiesel: Current scenario. Renew Sustain Energ Rev. 13, 1646, 2009.

5. ZUTA C.P., SIMPSON B.K., CHAN H.M., PHILLIPS L. J Am Oil Chem Soc. 80, 933, 2003.

6. ESLICK G.D., HOWE P.R.C., SMITH C., PRIEST R., BENSOUSSAN A. Benefits of fish oil supplementation in hyperlipidemia: a systematic review and meta-analysis. Int J Cardiol. 136, 4, 2009.

7. AFILAL M., ELASRI O., MERZAK Z. Mater J. Environ Sci. 5, 1160, 2014.

8. AMIN A., GADALLAH A., EL-MORSI A.K., EL-IBIARI N.N., EL-DIWANI G.I. Egypt J Pet. 25, 509, 2016.

9. BEHÇET R. Fuel Process Technol. 92, 1187, 2011.

10. GODIGANUR S., SURYANARAYANA M.C., REDDY R.P. Renewable Energy. 35, 355, 2010.

11. OUANJI F., NACHID M., KACIMI M., LIOTTA L.F., PULEO F., ZIYAD M. Chin J Chem Eng. 24, 1178, 2016.

12. SANTOS C.E.D., SILVA J.D., ZINANI F., WANDER P., GOMES L.P. Renewable Energy. 80, 331, 2015.

13. CHERNG-YUAN L., RONG-JI L. Fuel Process Technol. 90, 130, 2009.

14. NANTHA G.K., PAL A., SHARMA S., SAMANCHI C., SATHYANARAYANAN K., ELANGO T. Investigation of emissions and combustion characteristics of a CI engine fueled with waste cooking oil methyl ester and diesel blends. Alex Eng J. 53, 281, 2014. doi:10.1016/j. aej.2014.02.003

15. NABANITA B., RITICA R., TUSHAR J. Biodiesel production from used vegetable oil collected from shops selling fritters in Kolkata. Energy Procedia. 54, 161, 2014.

16. CHEUNG C.S., MAN X.J., FONG K.W., TSANG O.K. Effect of waste cooking oil biodiesel on the emissions of a diesel engine. Energy Proceed. 66, 93, 2015. https:// doi:10.1016/j.egypro.2015.02.050. 
17. LAPUERTA M., JOSE O.A., FERNA'NDEZ R. Effect of biodiesel fuels on diesel engine emissions. Prog Energy Combust Sci. 34, 198, 2008.

18. WIRAWAN S.S., TAMBUNAN A.H., DJAMIN M., NABETANI $H$. The effect of palm biodiesel fuel on the performance and emission of the automotive diesel engine. Agricultural Engineering International: The CIGR E journal Manuscript EE 07 005. X, 1, 2008.

19. KALLIGEROS S, ZANNIKOS F, STOURNAS P. An investigation of using biodiesel/marine diesel blends on the performance of a stationary diesel engine. Biomass and Bioenergy. 24, 141, 2003.

20. ISLAM M.S., AHMED A.S., ISLAM A., ABDUL AZIZ S., XAIN L.C., MRIDHA M. Study on emission and performance of diesel engine using castor biodiesel. Journal of Chemistry. 14, 1, 2014.

21. NADAL H.A., KHALED A.A. Comparative study of almond biodiesel-diesel blends for diesel engine in terms of performance and emissions. BioMed Research International. 201, 1, 2015.

22. NABI M.N., RAHMAN M.M., AKHTER M.S. Biodiesel from cotton seed oil and its effect on engine performance and exhaust emissions. Applied Thermal Engineering. 29, 2265, 2009.

23. GOWTHAMAN S., VELMURUGAN K. Performance and emission characteristics of direct injection diesel engine using biodiesel with Scr technology. International Journal of Engineering Research and Applications. 2, 1083, 2012.

24. GOPAL K.N., KARUPPARAJ R.T. Effects of pongamia biodiesel on emission and combustion characteristics of Diesel compression ignition engine. Ain Shams Engineering Journal. 6, 297, 2015.

25. RAO Y.V.H., VOLETI R.S., HARIHARAN V.S., RAJU A.V.S, REDD P.N. Use of Jatropha oil methyl ester and its blends as alternative fuel in diesel engine. Journal of the Brazilian Society of Mechanical Sciences and Engineering. 31, 253, 2009.

26. OBERWEIS S., AL-SHEMMERI T.T. Effects of biodiesel blending on emissions and efficiency in a stationary diesel engine. Being full length of paper presented at International Conference on Renewable Energies and Power Quality (ICREPQ’10) Granada Spain; 2010.

27. LENIN A.H., RAVI R., THYAGARAJAN K. Performance characteristics of a diesel engine using Mahua biodiesel as alternate fuel. Iranica Journal of Energy \& Environment. 4, 136, 2013.

28. BRAHMA H.S, BABU A.V. An experimental investigation on emissions of neat Mahua biodiesel using Urea-SCR. International Journal of Scientific \& Technology Research. 2, 39, 2013

29. UMESH T., MANJUNATH H.N., RUKMANGADHA P., MADHU D. Experimental study of performance and emission analysis of rice bran oil as an alternative fuel for an I.C engine. IOSR Journal of Mechanical and Civil engineering. 11, 130, 2014.

30. TESFA B., GU F., MISHRA R., BALL A. Emission characteristics of a CI engine running with a range of biodiesel feedstocks. Energies. 7, 334, 2014.

31. KOTIL R.V., PRAKASH S.B., KIRAN K., RAVIKUMAR T. An investigation on the performance and emission characteristics of a direct injection diesel engine using safflower oil and milk scum oil as a biodiesel. International Refereed Journal of Engineering and Science. 3, 19, 2014.
32. KAANAGBARA L., INYANG H.I., WU J., HILGER H. Aromatic and aliphatichydrocarbon balance in electric transformer oils. Fuel, 89, 3114, 2010.

33. MURUGAN S., RAMASWAMY M.C., NAGARAJAN G. The use of tyre pyrolysis oil in diesel engines. J. Waste Manag. 28, 2743, 2008.

34. LEE W.J. LIU Y.C., MWANGI F.K., CHEN W.H., LIN S.L., FUKUSHIMA Y., LIAO C.N., WANG L.C. Assessment of energy performance and airpollutant emissions in a diesel engine generator fueled withwatercontainingn ethanol-biodiesel-diesel blend of fuels. Energy 36, 5591, 2011

35. MANI M., SUBASH C., NAGARAJAN G. Performance, emission and combustioncharacteristics of a CI diesel engine using waste plastic oil. Appl. Therm. Eng. 29, 2738, 2009.

36. ARPA O., YUMRUTA S.R., ARGUNHAN Z. Experimental investigation of the effects of diesel-like fuel obtained from waste lubrication oil on engine performance and exhaust emission. Fuel Process. Technol. 91, 1241, 2010.

37. ARPA O., YUMRUTAS R., KASKA Ö. Desulfurization of diesel-like fuel produced from waste lubrication oil and its utilization on engine performanceand exhaust emission. Appl. Therm. Eng. 58, 374, 2013.

38. QASIM M., ANSARI T.M., HUSSAIN M. Experimental investigations on a diesel engine operated with fuel blends derived from a mixture of Pakistani waste tyre oil and waste soybean oil biodiesel, Environ Sci Pollut Res. 2017 https://doi.org/10.1007/s11356-017-0380-9.

39. QASIM M., ANSARI T., HUSSAIN M. Combustion, Performance, and Emission Evaluation of a Diesel Engine with Biodiesel Like Fuel Blends Derived from a Mixture of Pakistani Waste Canola and Waste Transformer Oils. Energies. 1023, 2017. https://doi:10.3390/en10071023.

40. HEYWOOD J.B. Internal Combustion Engine Fundamentals; McGraw-Hill Inc New York USA. 509, 1988.

41. CHAUHAN B.S., KUMAR N., CHO H.M. A study on the performance and emission of a diesel engine fuelled with Jatropha biodiesel oil and its blends. Energy. 37, 616, 2012.

42. RAHEMAN H., PRAKASH JENA C., SNEHAL S.J. Performance of a diesel engine with blends of biodiesel (from a mixture of oils) and high speed diesel. Int J Energy Environ. 6, 1, 2013.

43. DHAR A., AGARWAL A.K. Performance, emissions and combustion characteristics of Karanja biodiesel in a transportation engine. Fuel. 119, 70, 2014.

44. KAKATI J., GOGOI T.K. Biodiesel production from Kutkura (MeynaspinosaRoxb. Ex.) fruit seed oil: Its characterization and engine performance evaluation with $10 \%$ and $20 \%$ blends. Energy Convers Manag. 121, 152, 2016.

45. HIRKUDE J.B., PADALKAR A.S. Performance and emission analysis of acompression ignition: Engine operated on waste fried oil methyl esters. Appl Energy. 90, 68, 2012.

46. KHIARI K., AWAD S., LOUBAR K., TARABET L., MAHMOUD R., TAZEROUT M. Experimental investigation of Pistacialentiscus biodiesel as a fuel For directin injection diesel engine. Energy Convers Manag. 108, 392, 2016

47. OZSEZEN A.N. CANAKCI, M. Determination of performance and combustion characteristics of a diesel 
engine fueled with canola and waste palm oil methyl esters. Energy Convers Manag. 52, 108, 2011.

48. USTA N. An experimental study on performance and exhaust emissions of a diesel engine fuelled with tobacco seed oil methyl ester. Energy Convers Manag. 46, 2373, 2005.
49. DOLANIMI O., SHUAI L., ORLANDO J., RAJES AND TIEGANG F. Performance, Combustion, and emissions in a diesel engine operated with fuel in water emulsions based on ligin. Applied Energy. 154, 851, 2015.

50. MURUGAN S., RAMASWAMY M.C., NAGARAJAN G. The use of tyre pyrolysis oil in diesel engines. J Waste Manag. 28, 2743, 2008. 